RESEARCH NOTE

\section{Acute Diarrhea Associated with Heat-stable Enteroxin Producing Strains of Vibrio cholerae Non-O1: First Report from Cuba}

\author{
Laura Bravo/ ${ }^{+}$, Raúl Monté, \\ Mercedes Silva, Margarita Ramírez, \\ Belkys García, Anabel Fernández, \\ Gianni Rossolini*, Paolo \\ Guglielmetti*
}

Instituto de Medicina Tropical "Pedro Kourí", Código postal 601, La Lisa, Ciudad de La Habana, Cuba *Instituto di Malattie Infettive, Universitá di Siena, Via P. A. Mattioli, 10 I-53100, Siena, Italia

Key words: Vibrio cholerae Non-O1 - diarrhea heat-stable - enterotoxin

A five month old male infant was referred with watery diarrhea, vomiting and fever, to the paediatric ward of the provincial Pediatric Hospital of Las Tunas, Cuba. Abdominal examination revealed tenderness; liver and spleen were normal.

Chest, cardiovascular and other systems were normal. The patient was rehydratated with oral rehydratation with solution according to the World Health Organization formula and breast-feeding was continued. The clinical picture improved gradually and the patient was discharged after six days without diarrhea and in good condition. On admission stool sample was taken and cultured on Salmonella-Shigella and MacConkey agar for isolation of Salmonella, Shigella spp., enterotoxigenic and enteropathogenic Escherichia coli, Vibrio spp., Aeromonas spp., and Plesiomonas shigelloides (JF McFaddin 1980, p. 19-34. Biochemical Test for Identification of Medical Bacteria, 2nd ed., The Williams and Wilkins Co, Baltimore).

Blood agar suplemented with Butzler's antimicrobials was employed for the isolation of Campylobacter spp. The presence of Rotavirus was ruled out by latex agglutination assay. Three dif-

+Corresponding author. Fax :+53-7-336051

Received 10 April 1997

Accepted 8 January 1998 ferent samples of feaces were analyzed by conventional microscopic examination for the presence of ova, cyst or vegetative forms of parasites (Organización Mundial de la Salud 1992, p. 1020, Métodos Básicos de Laboratorio en Parasitología Médica, OMS, Geneva).

The stool specimen plated on MacConkey agar yielded a pure culture of lactose non-fermenting Gram-negative rods, moved by polar flagella, identified at genus level as Vibrio. The national strategy for cholera control in Cuba shows that the country is still free from cholera. A slide agglutination with polyvalent $\mathrm{O} 1$ group antiserum for presumptive identification of $V$. cholerae $\mathrm{O} 1$ strain was performed; the test was negative.

The coproparasitological examination was negative and no Rotavirus or other bacterial enterophatogen were found or isolated from stool samples. The Vibrio strain isolated was sent to the National Reference Laboratory for Diarrhoeal Diseases and Cholera Control at the "Pedro Kourí" Institute of Tropical Medicine, Havana City, and confirmed to be a non-O1 and non-O139 $\mathrm{V}$. cholerae by standard methods (JJ Farmer \& FW Hickman Brenner 1992, p. 2552-3011. In A Ballows, HG Truper, M Dworkin, W Harder, KH Schleifer (eds), The Prokaryotes: a Handbook on the Biology of Bacteria, Vol. 3, Springer, Verlag, New York). The strain was susceptible to 10 - and $150 \mu \mathrm{g}$ disks of the vibriostatic agent $\mathrm{O} / 129$; the antimicrobial susceptibility test, performed with the Kirby-Bauer method, showed that the strain was susceptible to tetracycline, ampicillin, cloramphenicol, trimethoprim, sulphametoxazol, nalidixic acid, ciprofloxacin, streptomycin, erytromycin, gentamicin, cefuroxime and furazolidone (CW Stratton \& RC Cooksey 1991, p. 1153-1165. In A Balows, WJ Hausler Jr, KL Herrmann, HD Isenberg, HJ Shadomy (eds), Manual of Clinical Microbiology, 5th ed., ASM, Washington, DC). The strain was analyzed for the presence of genomic sequences related to the $V$. cholerae $\mathrm{O} 1$ ctx genetic element, that includes the cep, orFU, ace, zot, and $\operatorname{ct} x A B$ genes, by using a colony-blot hybridization procedure (T Karasawa et al. 1993 FEMS Microbiol Letters 106: 143-146). The hybridization probe used was a $4.4 \mathrm{kbp}$ cloned DNA fragment containing the entire ctx element of $V$. cholerae, and was labeled with (a 32P) dCTP by the random priming technique.The presence of a heat-stable enterotoxin gene was investigated by PCR amplification as previously described (P Guglielmetti et al. 1994 Mol Cell Probes 8: 3944). The biological activity of the strain was tested by the conventional suckling mouse assay (Y Takeda et al. 1979 Infec Immun 25: 978-985). The results of the molecular characterization of the 
strain demonstrated the absence of any ctx genetic element related-sequences (data not shown) and the presence of the stn gene (Fig.): the suckling mouse assay confirmed the production and the activity of the heat-stable enterotoxin (ST).



Polymerase chain reaction (PCR) detection of sto gene in the strain of Vibrio cholerae non-O1 isolated from the patient (lane 1) and in a positive control strain (lane 2). In the lane 3 the $\mathrm{Mr}$ markers. PCR primers for sto open reading frame yielding an amplimer of $238 \mathrm{bp}$.
The role of non-O1 V. cholerae strain as intestinal pathogens is well established (JG Morris 1994 p. 103-115. In IK Wachsmuth, PA Blake, O Olsvik (eds), Vibrio cholerae and Cholerae: Molecular to Global Perspectives, ASM, Washington DC); some strains isolated from patients with diarrhea may produce toxins related to those encoded by the $V$. cholerae ctx genetic or an ST, similar to those expressed by E. coli (S Amito et al. 1992 Eur J Biochem 129: 257-263), Yersinia enterocolitica (JG Morris $1990 \mathrm{~J}$ Clin Invest 85: 697-705) and V. mimicus (M Arita 1991 FEMS Microbiol Letters 79: 105-110). The role for ST as virulence factor has been demonstrated in experimental assays and some studies have established the importance of non-O1 V. cholerae strain which produce only the ST in acute gastroenteritis (K Bagchi et al. $1993 \mathrm{~J}$ Clin Microbiol 31: 1315-1317). The strain isolated in this patient was positive for the stn gene by PCR assay and the ST production was confirmed by the conventional suckling mouse test; the same strain was negative for all elements of the $V$. cholerae $\mathrm{O} 1$ ctx genetic element. The absence of other viral, bacterial and protozoal pathogens indicates the likelihood that the strain isolated in the diarrhea of this child, the ST, is an important virulence determinant. This case is the first reported in Cuba and, to the best of our knowledge, in the Caribbean and Central America. From an epidemiological point of view the case is also interesting due to the age of the infant, the absence of sea food comsumption from his dietary history and the geographical origin of the patient, coming from an area of the island, far away from the sea coast.

Other studies have already been planned to better understand the epidemiology and clinical relevance of $V$. cholerae non-O1 strains in this still cholera-free geographical location. 